\title{
Die sing van psalms in die erediens: Twintig jaar later
}

\author{
Author: \\ Jacoba H. van Rooy ${ }^{1}$ \\ Affiliation: \\ ${ }^{1}$ School of Ecclesiastical \\ Studies, Faculty of Theology, \\ North-West University, \\ Potchefstroom Campus, \\ South Africa \\ Correspondence to: \\ Jacoba van Rooy \\ Email: \\ herrie.vanrooy@nwu.ac.za \\ Postal address: \\ PO Box 19217, Noordbrug \\ 2522, South Africa \\ Dates: \\ Received: 26 May 2011 \\ Accepted: 03 Aug. 2011 \\ Published: 21 Oct. 2011 \\ How to cite this article: \\ Van Rooy, J.H., 2011, 'Die \\ sing van psalms in die \\ erediens: Twintig jaar later', \\ Verbum et Ecclesia 32(1), Art. \\ \#555, 9 pages. doi:10.4102/ \\ ve.v32i1.555
}

About 20 years ago the HSRC (Human Sciences Research Council) conducted an empirical investigation on the singing of psalms in three Afrikaans reformed churches. Vos and Müller (1990) dealt with different aspects of this investigation, especially the questions of which melodies are sung in the churches, what the frequency of the use of the different psalms is, the way in which new songs are introduced, the situation in the different churches and the influence of church attendance on the love of the psalms. In an investigation undertaken in 2008 (Van Rooy 2009) these matters were investigated in the Reformed Churches in South Africa, a denomiation that introduced a new hymnal in 2003. The comparison of the two investigations revealed that the number of favourite psalms and the same psalms remained fairly constant. The acceptance of new hymns is related to a number of factors, especially the melody and the liturgical usefulness of the new hymns. The new metrical version of the psalms is still not used very frequently in the Reformed Churches in South Africa. This can partly be ascribed to the lack of structured programmes to learn the new hymns.

\section{Inleiding}

Ongeveer 20 jaar gelede is 'n empiriese ondersoek deur die Raad vir Geestelike Navorsing (RGN) gedoen na die sing van die Psalms in drie van die Afrikaanse Kerke (NG, Hervormd en Gereformeerd) in opdrag van die Breë Psalmberymingskommissie. Sarita Hauptfleisch van die RGN het die ondersoek gedoen en in Mei 1990 afgehandel (vgl Vos \& Müller 1990:89). Vos en Müller (1990) het aan verskillende aspekte van hierdie ondersoek aandag gegee. Hulle gebruik sekere vrae wat in die ondersoek aan die orde gestel is, in hulle navorsing. Die RGN moes op versoek aan die volgende aspekte aandag gee (Vos \& Müller 1990:89):

- Watter melodieë word in kerke gesing en watter nie?

- Hoe dikwels word die onderskeie psalms gesing?

- Hoe word nuwe psalms aangeleer?

- Wat is die situasie in die verskillende kerke?

- Watter invloed het kerkbesoek op 'n liefde vir psalms?

In 'n studie oor die gebruik van die Psalmboek 2003 in die Gereformeerde Kerke in Suid-Afrika (GKSA; Van Rooy 2009) is onder andere aandag gegee, in aansluiting by Vos en Müller, aan die eerste drie sake hierbo genoem. In hierdie artikel word 'n vergelyking getref tussen die bevindinge van Vos en Müller en die ooreenstemmende bevinding in die ondersoek wat in 2008 in die Gereformeerde Kerke in Suid-Afrika (GKSA) gedoen is. Die RGN-ondersoek was gerig op die beryming van die psalms wat in 1936 voltooi is (die Totiusberyming). Die ondersoek van 2008 het gehandel oor die Psalmboek 2003, wat in die GKSA in gebruik is. Die boek bevat die Totiusberyming en ook die 2001-omdigting. Die vergelyking wat in hierdie artikel getref word, handel nie oor die verskille tussen die twee berymings nie, maar oor faktore wat die sing van psalms in die algemeen bevorder of wat negatief inwerk op die sing van psalms in die algemeen en spesifieke psalms in die besonder.

\section{Die studie van Vos en Müller (1990)}

Vos en Müller het volgens die Prakties Teologiese metode van Zerfass (1988) te werk gegaan, waar onder meer ' $n$ wetenskaplike proses in drie vlakke onderskei kan word, naamlik ' $n$ verfyning van teologiese teorieë, 'n fokus op die empirie en 'n verstelling van die praktykteorie na aanleiding van die beginsels van die eerste twee vlakke. Die basisteoretiese beginsel gaan van die veronderstelling uit dat die erediens as ' $n$ kommunikatiewe handelingsruimte beskou word waarbinne God en sy verbondsvolk beweeg: God handel met en deur sy Woord, terwyl sy Gees mense daartoe beweeg om ook te handel. Hierdie handelinge bied die geleentheid om God se heil onbelemmerd te kommunikeer en te vier. Binne so ' $n$ konteks sal aandag gegee kan word aan die gemeente as draer van die lied en aan die lied as vertolker van die evangelie. So lewer die gemeente diens aan God en daardeur hang die funksies van die lied ten nouste saam met
(C) 2011. The Authors. Licensee: AOSIS OpenJournals. This work is licensed under the Creative Commons Attribution License. 
die diens van die gemeente in die erediens (Vos \& Müller 1990:86-87). Vos en Müller (1990:87-88) bespreek vervolgens die funksies van die psalms in die Ou Testament en in die erediens, asook die melodie as draer van die lied. Musiek het ' $n$ dienende funksie in die erediens en moet daarop gerig wees om die gemeente in staat te stel om hom met die teks te identifiseer en hom met die sing daarvan te kan uitleef (Vos \& Müller 1990:88).

Wat die empiriese fase van die artikel betref, het Vos en Müller gebruik gemaak van gegewens wat bekom is uit die RGN-ondersoek. In die ondersoek is 'n vraelys gebruik wat aan predikante, orreliste en gemeentelede gerig was (Vos \& Müller 1990:89). Die vraelys aan gemeentelede het uit drie afdelings bestaan. Die eerste afdeling het gehandel oor biografiese gegewens, musiekagtergrond, die sing van psalms tydens huisgodsdiens en die aanleer van die psalms, die tweede oor die mees geliefde psalms en die derde oor lidmate se houding ten opsigte van die kerk en die sing van psalms.

Die vraelys aan predikante het vier afdelings gehad. Die eerste het ooreengestem met die eerste afdeling by lidmate. Die tweede het gehandel oor hoe gereeld die onderskeie psalms in die betrokke gemeente gesing word en die rede waarom sekere psalms selde of nooit gesing word nie. Derdens is probeer om vas te stel watter melodieë en berymings die mees geliefde is en watter melodieë by die berymings, na die oordeel van die respondent, vervang kan word. Die vierde afdeling het die respondent se benadering tot die sing van die psalms in die erediens bepaal (Vos \& Müller 1990:89).

Die vraelys aan die orreliste het grotendeels met dié van die predikante ooreengestem. In die eerste afdeling is 'n aantal vrae oor die orrelis se musiekopleiding bygevoeg, terwyl daar nie in die derde afdeling van hom of haar verwag is om uitspraak te lewer oor die beryming van die psalms nie. Die vierde afdeling het 'n aantal vrae oor die sangleiding in die betrokke gemeente gevra. Laastens is die orrelis versoek om oor 'n tydperk van 4 weke alle liedere wat voor en tydens die erediens gesing is, aan te teken (Vos \& Müller 1990:90).

Gemeentelede is betrek en geografiese ligging, ouderdom en sosio-maatskaplike omstandighede is in ag geneem. Psalmmelodieë wat in die 1978-psalmbundel opgeneem is, was ter sprake. Die vraelyste is aan 150 gemeentes landswyd gestuur. Elk van die Gereformeerde, Hervormde en NG Kerkverbande sou aan 50 gemeentes vraelyste uitstuur. Die steekproef is gestratifiseer volgens kerkverband en dorpgrootte (Vos \& Müller 1990:90).

Wat betref die frekwensie van psalms kom Vos en Müller (1990:91) tot die gevolgtrekking dat daar aansienlik meer psalmmelodieë is wat nooit gesing word nie, as wat daar psalms is wat gereeld gesing word. In gevalle waar psalms selde indien ooit gesing word, het die oorgrote meerderheid van die respondente die onbekende melodie as rede aangevoer, ' $n$ kleiner persentasie het die melodie as problematies ervaar en in enkele gevalle is die psalm vanweë die woorde nie gesing nie (Vos \& Müller 1990:94).

Betreffende die mees geliefde psalms is sterk ooreenkomste bevind ten opsigte van die voorkeurmelodieë van die respondente. Die Geneefse melodie is nie besonder gewild nie en die mees geliefde melodieë word gereeld in die kerk gesing. Waarom is sommige psalms meer geliefd as ander? Vir sommige lidmate is dit ' $n$ melodie waarmee hulle grootgeword het, vir sommige spreek die psalms tot hulle en vir sommige is die melodie bloot mooi. Die gepastheid van die melodie by die woorde speel nie 'n groot rol nie. Predikante se grootste rede vir die geliefdheid van ' $n$ psalm is die feit dat ' $n$ betrokke psalm hulle aanspreek. Vir orreliste is die gepastheid van die woorde die sterkste rede. Duidelik is daar betekenisvolle verskille in voorkeure vir sekere psalms tussen lidmate, predikante en orreliste. Dit is ook van waarde dat redes vir die geliefdheid van 'n psalm deur tradisie beïnvloed word. Lidmate se houding ten opsigte van psalmsang is positief, $92 \%$ van die lidmate beskou sang as 'n wesenlike deel van die erediens, $94 \%$ let op die woorde terwyl gesing word en $63 \%$ stel daarin belang om deel te neem aan 'n projek om psalmsang te bevorder (Vos \& Müller 1990:89-96).

Die resultate van die RGN-ondersoek het 'n belangrike rol gespeel in die beoordeling van watter melodieë wel in die 2001-omdigting gebruik sou word. Die belangrikste rede wat aangegee is waarom sekere psalms min of glad nie gesing word nie, was die onbekendheid van die melodie. Nog ' $n$ rede was dat die betrokke melodie as problematies ervaar is en in enkele gevalle is die inhoud van die psalm as rede aangevoer (Vos \& Müller 1990:94). Wat die psalmmelodieë betref, word die 20 mees geliefde psalms in Tabel 1 aangegee, wat later bespreek sal word.

\section{Die studie van Van Rooy (2009)}

Die skrywer van hierdie artikel het in 2009 'n proefskrif voltooi oor die Psalmboek 2003 as kommunikasiemiddel in die erediens. Hierdie studie het ook die model van Zerfass gevolg (Van Rooy 2009). In die basisteoretiese gedeelte is aandag gegee aan die lied in die Bybel asook enkele belangrike aspekte van die kerklied deur die eeue. In die metateoretiese gedeelte is in die besonder aandag gegee aan aspekte van kommunikasie van belang vir die kerklied, asook aan musikale aspekte van belang vir die studie. Die empiriese ondersoek het kwantitatiewe en kwalitatiewe tegnieke ingesluit. Dingemans (1996:64) wys daarop dat dit tipies is van die benadering wat in hierdie studie gebruik word, in aansluiting by Zerfass, om die twee metodes in die navorsing te gebruik. Van der Merwe (1996:290) toon aan dat kwantitatiewe tegnieke gerig is op die toetsing van teorieë en die vasstelling van data soos feite en statistiese beskrywings. By kwalitatiewe navorsing lê die klem meer op die verstaan van menslike gedrag en ervaring (Van der Merwe 1996:291). Yates (2004:138) omskryf kwalitatiewe data as dinge wat 'n mens in die wêreld vind wat betekenis 
vir die mens het. Dit handel oor die insig daarin. Dingemans (1996:64) stel dit kortliks dat kwantitatiewe benaderings die werklikheid probeer beskryf en verklaar, terwyl kwalitatiewe benaderings probeer om mense se verskillende opvattings en interpretasies van die werklikheid te beskryf.

In hierdie studie word resultate van die twee metodes in verband gebring. Hieroor sê Gottlieb (2006:48) dat kwalitatiewe navorsing probeer verklaar wat kwantitatiewe waarnemings vir 'n spesifieke individu beteken. Vir die kwantitatiewe navorsing is in die besonder gebruik gemaak van opnames van die liedere wat gesing is en van die stand van sake ten opsigte van gemeentesang. Opnames soos wat hier gemaak is, is veral beskrywend van aard (vgl Van der Merwe 1996:296). Vir die kwalitatiewe data is gedeeltelik gebruik gemaak van oop vrae in die vraelys en van persoonlike onderhoude. Die doel van die onderhoude was om die gekose persone se siening te kry oor verskillende aspekte wat met die navorsing verband hou (vgl. Marais en Bondesio 1996:137).

In die eerste fase is 'n versoek aan predikante van die GKSA gerig om 'n opgawe te voorsien van die liedere wat gedurende 1 jaar tydens eredienste gesing is. Die versoek is op 27 Mei 2008 gerig aan alle predikante van die GKSA wie se elektroniese adresse beskikbaar was. Die terugvoer op hierdie versoek was redelik goed, met die gevolg dat meer as 50 predikante inligting gestuur het tot November 2008. Hierdie inligting het gekom van predikante wat die Psalmboek 2003 gebruik en van predikante wat die Psalmboek 2000 gebruik. ${ }^{1}$ Sommige het net 'n lys van liedere wat gesing is, gegee, terwyl ander die volledige liedere vir 'n jaar gegee het. 'n Volledige uiteensetting van al die gegewens word aangetref in Van Rooy (2009:531-536).

In die tweede fase is drie vraelyste op 27 Oktober 2008 uitgestuur na predikante van die GKSA, gerig op verspreiding na onderskeidelik predikante, orreliste en lidmate van die GKSA. Hierdie vraelyste dek'n verskeidenheid van sake wat vir die ondersoek van belang is, waarvan net die relevante gedeeltes vir hierdie artikel uitgesoek is.

Daar is op verskillende plekke in die vraelys aan respondente die geleentheid gegee om aanvullende opmerkings te skryf, met 'n oop vraag oor enige verdere kommentaar aan die einde van die vraelys. Verskeie van die respondente het van die geleentheid gebruik gemaak. Van die inligting word op toepaslike plekke in die bespreking gebruik.

In die vraelyste is onder andere aandag gegee aan die drie sake van die ondersoek van Vos en Müller hierbo vermeld. 'n Vergelyking van die bevindinge van Vos en Müller kom in die volgende afdeling aan die orde.

\footnotetext{
1.Die twee psalmboeke word beide in die GKSA gebruik. Die Psalmboek 2000 bevat die 1936-beryming en Skrifberyminge deur verskillende sinodes van die GKSA gebruik. Die Psalmboek 2003 bevat ook bogenoemde, maar ook die 2001-omdigting van die 150 psalms.
}

\section{Watter melodieë in kerke gesing word en watter nie}

In hierdie onderafdeling word 'n vergelyking getref tussen die gegewens oor liedere wat gesing word volgens die ondersoek van Van Rooy (2008) en die gegewens volgens die RGN-ondersoek soos gerapporteer deur Vos en Müller (1990). Beide ondersoeke het die respondente gevra om die mees geliefde psalms aan te dui.

Vos en Müller (1990:94) se gegewens oor die mees geliefde psalmmelodieë soos dit verwys na die 1936-beryming van die psalms, word aangedui in Tabel 1. Hierbenewens het hulle ook op die melodieë gekonsentreer, sodat alternatiewe melodieë by psalms apart bereken is. Daar is egter nie een geval waar beide die melodieë op die tabel voorkom nie. Dit dui daarop dat die alternatiewe melodieë oorheersend gebruik is. In die tabel word die liedere aangedui in die volgorde waarin dit die meeste by respondente voorkom.

Vos en Müller wys daarop dat 15 van die psalms in al drie die kolomme voorkom, naamlik Psalm 8, 23, 25, 33, 42, 46, 48, 66, 68, 84, 91, 100, 105, 116 en Psalm 146.

In die navorsing wat vir die studie van 2009 gedoen is, is navraag gedoen na die mees geliefde psalms uit die 1936-beryming en uit die 2001-omdigting. Vir die doel van hierdie artikel word gefokus op die 1936-beryming. Gegewens oor die mees geliefde psalms van die 1936-beryming by predikante, orreliste en lidmate van die GKSA volgens die ondersoek van 2008, is in volgorde van voorkeur getabelleer (Tabel 2). In die vraelyste wat uitgestuur is, is die predikante, orreliste en lidmate gevra om die vyf bekendste of mees gebruikte liedere aan te dui.

\begin{tabular}{lll}
\multicolumn{2}{l}{ TABEL 1: Die mees geliefde psalmmelodieë soos bevind deur Vos en Müller. } \\
\hline Predikante & Orreliste & Lidmate \\
\hline 100 & 42 & 33 \\
105 & 84 & 23 \\
42 & 33 & 100 \\
84 & 23 & 84 \\
$23 a$ & 100 & 146 \\
33 & 116 & 42 \\
48 & 48 & 48 \\
146 & 146 & 8 \\
116 & 91 & 116 \\
8 & 66 & 130 \\
25 & 9 & 25 \\
89 & $46 w$ & 91 \\
66 & 25 & 18 \\
46 & 107 & 46 \\
68 & 8 & 66 \\
91 & 128 & 89 \\
107 & 150 & 147 \\
9 & 98 & 38 \\
118 & 105 & 105 \\
128 & 31 & 68 \\
- & 68 & - \\
\hline
\end{tabular}

Bron: Vos, C.J.A. \& Müller, J.C., 1990, 'Die sing van psalms in die erediens:'n Kommunikatiewe handelingsteoretiese perspektief', Praktiese Teologie in Suid-Afrika 6(1), 86-98. 
TABEL 2: Gewildste psalms uit die 1936-beryming by predikante, orreliste en lidmate van die GKSA.

\begin{tabular}{lll}
\hline Predikante & Orreliste & Lidmate \\
\hline 100 & 146 & 100 \\
146 & 100 & 146 \\
33 & $23 a$ & $23 a$ \\
18 & 116 & 116 \\
$23 a$ & 42 & 33 \\
116 & 48 & 150 \\
25 & 46 & 8 \\
150 & 9 & 42 \\
48 & 10 & 84 \\
42 & 66 & 38 \\
84 & 68 & 48 \\
38 & 118 & 18 \\
89 & 145 & 25 \\
118 & 84 & 119 \\
8 & 38 & 134 \\
107 & 107 & 2 \\
145 & - & $130 a$ \\
$130 a$ & - & 46 \\
119 & - & 68 \\
148 & - & 107 \\
1 & - & 128 \\
- & - & 147 \\
\hline- & - & 1 \\
\hline
\end{tabular}

GKSA, Gereformeerde Kerke in Suid-Afrika.

Wat dadelik opval, is dat daar ' $\mathrm{n}$ redelike mate van oorvleueling is by die twee stelle gegewens. By Vos en Müller was daar 15 psalms wat in al drie die kolomme voorkom, naamlik Psalm 8, 23, 25, 33, 42, 46, 48, 66, 68, 84, 91, 100, 105, 116 en Psalm 146. Van hierdie 15 psalms kom 10 voor by al drie die groepe van die ondersoek van 2008, naamlik Psalm 8, 23, 25, 33, 42, 48, 84, 100, 116 en Psalm 148. Hierbenewens kom Psalm 46 en Psalm 68 by twee van die drie groepe voor. Net 2 van die 15 psalms by Vos en Müller kom glad nie voor by al die drie groepe uit 2008 nie, naamlik Psalm 91 en Psalm 105. Van die psalms wat by al drie groepe van 2008 voorkom, kom Psalm 38 en Psalm 107 nie by Vos en Müller voor nie. Psalm 107 kom wel voor by hulle predikante en orreliste en Psalm 38 by lidmate.

Daar is ook 'n aantal psalms wat relatief dikwels in die ondersoek van 2008 voorkom, maar minder by Vos en Müller. Dit sluit in Psalm 118, 119, 130, 145 en Psalm 150. Uit die vergelyking van die gegewens van 1990 en 2008 blyk dit duidelik dat daar ' $n$ relatief klein, maar bestendige, groep psalms is wat gewild gebly het.

Die vraag kan wel gevra word waarom sommige liedere gewilder is as ander. Kloppenburg (1991) het in Nederland oor hierdie kwessie navorsing gedoen. Hy stel die vraag of dit te doen het met die woorde van die berymde psalm of die melodie (Kloppenburg 1991:233). Kloppenburg (1991:240) meen dat die oorsaak van die aanvaarding van 'n melodie nie noodwendig in die melodiestruktuur, die toonsoort wat gebruik word of die moeilikheidsgraad van die ritme gesoek moet word nie. Volgens hom lê die oorsaak eerder by die teks, veral in die strofebou. Ook deur die strofebou beweeg die psalms tussen volkslied en kunslied. Hy meen ook dat 'n melodie in die styl van 'n Renaissance-strofebou, met 'n kunstige rymskema van lang en kort reëls, minder kans het om geliefd te raak as een met 'n vierreëlstrofe of ' $n$ sesreëlstrofe, en 'n reëlmatige kadens.

Smelik (1999:128-129) wys daarop dat die beoordeling van melodieë 'n gewigtige saak is. Daar moet aanvaar word dat 'n lied sy eie taal en musiek het en mag hê. Daarbenewens behoort daar nie gekonsentreer te word op liedere wat vir die mens aanvaarbaar is en by die tydgees pas nie en gevolglik kan die keuse van die mees gewilde melodieë nie altyd goed gemotiveer word nie. Smelik (1999) toon aan dat mense 'n idee oor die kerkliedmelodieë vorm wat ongegrond is, naamlik dat dit traag, leweloos en ouderwets is en dat die styl baie eentonig is. Dit kan eerstens wees weens 'n reaksie teen die tradisie, waarin die Geneefse psalms 'n dominante plek inneem. Die geskiedenis van die kerklied dui egter die teendeel aan, naamlik dat daar 'n groot verskeidenheid melodietipes is waarteen daar besware ingebring kan word. Die Geneefse melodieë kan dus nie alleen die grond vir besware wees nie. 'n Tweede rede waarom mense die kerklied veroordeel, is vanweë die tempo, wat as te traag beskou word. Daar bestaan egter wel 'n groot verskeidenheid melodietipes en melodieë in die kerk (Smelik 1999:131).

Uit die vergelyking van die mees gewilde liedere in die twee ondersoeke hier ter sprake, is dit duidelik dat daar net meer as tien psalms in die 1936-beryming is wat steeds gewild is. Die volgende psalms kan as deel van hierdie groep beskou word: Psalm 8, 23, 25, 33, 42, 46, 48, 68, 84, 100, 116 en Psalm 148. Hierdie stand van sake verduidelik nog nie waarom juis hierdie psalms die gewildste is nie, maar dit sal in die volgende onderafdeling aan die orde kom.

\section{Die frekwensie van die sing van verskillende psalms}

Sowel Vos en Müller (1990) as die ondersoek van 2008 het hieraan aandag gegee. In vier tabelle $(3.1,3.10,4.1$ en 4.10$)$ verskaf Vos en Müller (1990) gegewens ten opsigte van psalms wat wel, of nie, gesing word, soos blyk uit die ondersoek waaroor hulle verslag doen (Vos \& Müller 1990:90-93). Hulle ondersoek het nie berus op 'n opname van die liedere wat oor 'n periode gesing is nie, maar op die oordeel van predikante en orreliste oor watter liedere gereeld of nooit gesing is nie. Ter wille van die vergelyking word, wat die predikante betref, eers gelet op die liedere wat na hulle oordeel baie gereeld gesing is. Hulle moes eers aandui watter psalms baie gereeld gesing word en daarna watter psalms nooit gesing word nie. Verder het hulle ook onderskei tussen die twee psalms met alternatiewe berymings en dié waar daar alternatiewe melodieë was. Die psalms waar meer as 50\% van die predikante aangedui het dat dit baie gereeld gesing word (Vos \& Müller 1990:90), was Psalm 84, 100 en Psalm 146 $(60 \%+)$; Psalm 25, 33b, 42, 48, 105, 116, 118 en Psalm 134 (51\% - 60\%); Psalm 23A, 66, 68 en Psalm 89 (41\% - 50\%); en Psalm 46, 107B, 128, 138 en Psalm 150 (31\% - 40\%). 
In hulle Tabel 4.1 het Vos en Müller (1990:92) die gegewens aangebied van die orreliste se beskouing oor die psalms wat gereeld gesing is. Die psalms wat hulle aangedui het, is Psalm 134 (81\% - 90\%); Psalm 100 en Psalm 146 (71\% - 80\%); Psalm 33B, 42, 48, 66, 68 en Psalm 84 (61\% - 70\%); Psalm 25, 89, 105, 116 en Psalm 118 (51\% - 60\%); Psalm 23A, 36, 98 en Psalm 107B (41\% - 50\%); en Psalm 9B, 31B, 46, 91B en Psalm 128 $(31 \%-40 \%)$. Die psalms wat volgens meer as $30 \%$ van die predikante gereeld gesing word, is net 20, terwyl die orreliste 23 aangedui het. Daar is nie ' $n$ groot verskil tussen die twee stelle gegewens nie.

Die gegewens bekom van predikante in die GKSA oor die frekwensie van liedere wat gesing is, kan met bostaande vergelyk word. In die ondersoek van 2008 is predikante gevra om die liedere te voorsien wat hulle oor ' $n$ periode van ' $\mathrm{n}$ jaar laat sing het. Die bevindinge is dus gegrond op werklike syfers, en berus nie op die oordeel van die predikante nie. In Tabel 3 is die gegewens oor alle psalms van die 1936-beryming saamgevat (Van Rooy 2009:356).

Tabel 3 verskil aansienlik van die prentjie soos geskets deur Vos en Müller. In die tabel is die psalms in 11 groepe verdeel. Die eerste 10 het intervalle van 25, terwyl Psalm 119 apart lê. Van die elf psalms wat volgens Vos en Müller die meeste gesing word, lê drie in die groep tussen 226 en 250 (Psalm 33, 105 en 118), drie tussen 201 en 225 (Psalm 25, 116 en 146), een tussen 176 en 200 (Psalm 84), twee tussen 151 en 175 (Psalm 48 en 100), een tussen 126 en 150 (Psalm 42) en een onder 100 (Psalm 134). Al die psalms sal wel deel wees van dié wat gereeld gesing word in die GKSA. Van die wat tans baie in die GKSA gesing word, verskyn sommige egter heelwat laer by Vos en Müller (1990:90). Psalm 119, wat die meeste gesing is, lê by hulle tussen $21 \%$ en $30 \%$; so ook Psalm 145. Psalm 89 lê by hulle tussen $41 \%$ en $50 \%$ en Psalm 18 en Psalm 40 tussen $11 \%$ en $20 \%$. Hierdie psalms is almal onder die twaalf wat die meeste in die GKSA gesing word. Wat by die vergelyking onthou moet word, is dat Vos en Müller se ondersoek gedoen is onder predikante van drie Afrikaanse kerke. Aangesien die GKSA nie gesange sing nie, is dit te verwagte dat die psalms by die predikante van die ander twee kerke minder bekend sal wees.

In dieselfde tabel van Vos en Müller (1990:90) kan ook gesien word watter psalms min gesing word. Onder die groep wat predikante aandui dat die liedere tussen $1 \%$ en $10 \%$ gesing word, is ' $n$ hele aantal liedere wat in die GKSA redelik gereeld gesing word, soos Psalm 1, 2, 4, 16, 20, 34, 47 en nog meer. Daar is ook liedere wat nie op die lys verskyn nie, soos Psalm 5. Betreffende liedere wat nie gesing word nie, is Vos en Müller (1990:91) se Tabel 3.10 van meer belang. Daarin is 'n lys van die liedere wat volgens die predikante nooit gesing word nie. Die liedere wat tussen $81 \%$ en $90 \%$ deur die predikante geplaas is onder die liedere wat nooit gesing word nie, val met enkele uitsonderings onder die groep psalms wat in die opname wat in 2008 gedoen is, minder as 25 keer gesing is. Die uitsonderings val in die volgende groep. Dieselfde geld vir die groep van Vos en Müller (1990) tussen 71\% en 80\%.
TABEL 3: Frekwensie van Psalms van die 1936-beryming.

\begin{tabular}{|c|c|c|}
\hline Frekwensie & Getal liedere & Psalms \\
\hline $0-25$ & 80 & $\begin{array}{l}3,5,6,7,10,11,12,13,14,15,17,21,22,23 b, 24, \\
26,28,29,30,35,39,41,44,49,50,52,53,54, \\
55,56,57,58,59,60,61,62,63,64,67,89,70, \\
74,76,77,78,80,82,83,85,87,88,94,96,101, \\
102,106,108,109,110,111,112,113,114,115, \\
117,120,123,125,127,129,130 b, 131,132, \\
133,137,140,141,142,143,144\end{array}$ \\
\hline $25-50$ & 10 & $37,72,75,79,93,122,126,135,136,148$ \\
\hline $51-75$ & 12 & $1,4,16,20,27,43,71,73,95,97,104,124$ \\
\hline $76-100$ & 16 & $\begin{array}{l}2,8,34,36,38,45,46,47,51,81,90,91,99,134 \\
139,149\end{array}$ \\
\hline $101-125$ & 7 & $65,86,98,121,128,147,150$ \\
\hline $126-150$ & 7 & $19,32,42,92,103,107,138$ \\
\hline $151-175$ & 8 & $9,23 a, 31,48,66,68,100,130 a$ \\
\hline $176-200$ & 3 & $18,40,84$ \\
\hline $201-225$ & 4 & $25,116,145,146$ \\
\hline $226-250$ & 4 & $33,89,105,118$ \\
\hline $251+$ & 1 & $119(344)$ \\
\hline
\end{tabular}

Dus kan aanvaar word dat wat die psalms betref wat die minste gesing word, daar nie 'n groot verskil is tussen die opname van Vos en Müller (1990) en die opname van 2008 nie.

Vos en Müller (1990:94) het veral drie redes gevind waarom sekere psalms nie gesing word nie, naamlik 'n onbekende melodie, 'n problematiese melodie en in enkele gevalle vanweë die inhoud van die betrokke psalm.

Kloppenburg (1991:235-236) het in sy ondersoek in Nederland bevind dat van die 124 Geneefse psalmmelodieë daar 53 is wat byna nooit opgegee is nie, en ongeveer 30 melodieë wat dikwels gesing word, waaronder Psalm 8, 24, 36 en Psalm 130 die meeste gesing is. Kloppenburg het na die rymskema en aantal lettergrepe gaan kyk van nege van die psalms wat as die mees frekwente psalms aangedui is. Hieruit is bevind dat vyf van die nege psalms ' $n$ heel eenvoudige vierreëlige vorm het. Die psalms wat gewild en langer is, besit 'n opvallend reëlmatige opbou. Meestal word dit verder versterk deur die melodiestruktuur wat gewoonlik fraseherhaling of motiefherhaling vertoon. In Psalm 66, byvoorbeeld, stem frases 1 en 3 en frases 4 en 8 ooreen. Dit is 'n samestelling wat sterk oorhel na die bar-vormtegniek. Psalm 36 vertoon baie lank met sy 12 frases, maar is meer konsekwent in die bar-vorm geskryf as Psalm 66. Buitendien is die tweede laaste frase 'n sekwens van die derde laaste frase en die laaste frase 'n gewysigde sekwens van die tweede laaste frase. Die melodiese vormskema lyk soos volg: ABC ABC FF'F". Hierdie strofevormskema kom reëlmatig voor in beide die volksliedrepertorium en die kerkliedrepertorium (Kloppenburg 1991:241).

Vervolgens het Kloppenburg (1991:242) op dieselfde metode gaan kyk na die 36 psalms wat die minste opgegee is (glad nie of net een keer). Hy het die volgende bevind: dit bevat lang strofes, onreëlmatige of nie-simmetriese rymskemas, wat nêrens elders voorkom nie - sommige hoogstens in digbundels. 'n Unieke strofevormstruktuur veroorsaak dat liedere minder toeganklik is, moeiliker op die oor val en nie so maklik aanvaar word nie. Oor die algemeen kan die volgende gestel word: 
- Die gangbare modelle is die tipes wat die meeste voorkom en meer in die smaak van die kerkvolk val as die kunstige en die besondere. Die liedere wat oor 'n groot mate van oorspronklikheid beskik, is blykbaar nie in die kerklied gewens nie.

- Die modus (die toonaard) van die betreffende melodie speel nouliks 'n rol (Kloppenburg 1991:243).

In aansluiting by hierdie ondersoek, het Van Rooy (2009) tien liedere uit die Psalmboek 2003 gekies waarvan die melodieë ontleed word om te bepaal wat die invloed van die melodie mag wees op die frekwensie (hoog of laag) van die betrokke lied. Die liedere is gekies op grond van die terugvoer oor die frekwensie van die gebruik daarvan. Hierdie tien sluit in vyf liedere van die 1936-beryming en die oorspronklike Skrifberymings wat min gesing word en vyf liedere uit die 2001-omdigting en die nuwe Skrifberymings wat baie gesing word. Die vyf liedere wat min gesing is, is Psalm 3 (1936), 22 (1936 en 2011), 120 (1936), en Skrifberyming 2-3 en 11-1. Die wat baie gesing is, Psalm 29 (2001), 111 (2001), en Skrifberyming 3-4 (Lied 306), 7-2 en 12-3 (Lied 265). Die musikale ontleding van die liedere toon duidelik aan watter rol die melodie speel in die gebruik al dan nie van hierdie liedere (vgl Van Rooy 2009:385-413).

Cilliers (1979:84) maak die belangrike stelling dat 'n lied alleenlik doelmatig kan wees as dit singbaar is. Olivier (2001:43) het aandag gegee aan die vraag oor wanneer 'n melodie as singbaar beskryf kan word. Hy wys daarop dat die melodie die karakter van die teks behoort te verklank. Die teks van 'n loflied vereis 'n totaal ander karakter as dié van 'n boetelied. As die teks nie in die melodie weerspieël word nie, sal dit nie oortuig nie.

Pasveer (2001:329) maak die stelling dat die teks en melodie van die kerklied as kunswerk nie 'n doel op sigself is nie, maar ' $n$ middel. Die melodie mag die teks nie oorskadu nie; dit moet dien en nie heers nie. Dienende kuns is nie noodwendig minderwaardige kuns nie. Die kerklied moet deur almal gesing kan word. Dit hou in dat dit ritmies nie te ingewikkeld mag wees nie en die omvang nie te groot mag wees nie (Pasveer 2001:330).

Honders (1978:11-12) stel dit duidelik dat in die eenheid tussen teks en melodie gevra moet word na die kwaliteit van sowel teks as melodie. By die teks moet daar nie net sprake wees van reëls wat rym nie; dit moet sinne wees wat die inhoud sterk oordra, uiters gekonsentreerd, Bybels geïnspireerd, digterlik en eenvoudig; wat die geloofsinhoud duidelik verwoord. Die melodie moet ' $n$ karaktervolle en spanningsvolle samehang van tone vorm wat op die teks afgestem is en dit ondersteun. Die teks en melodie moet so sterk (afsonderlik en/of gesamentlik) wees, dat dit vra om herhaal te word, strofe op strofe, keer op keer.

Met die hersiening van die Afrikaanse psalmbundel, waaraan die werk reeds in 1953 begin is, is 'n aantal belangrike beginselbesluite geneem oor die hersiening van die melodieë (Van Wyk 1979:116):
- Die inhoud van die psalm en die melodie moet nie met mekaar in stryd wees nie.

- Die melodie moet eenvoudig wees en binne bereik van die menslike stem.

- Die melodie moet plegtig en verhewe wees.

- Die melodie moet gemaklik deur die gemeente gesing kan word.

- Nuwe wysies moet aanpas by die styl van die bestaande psalmmelodieë.

Daar is ook belangrike besluite geneem oor die hersiening van die melodieë, wat neerslag sou vind in die hersiene psalmboek van 1976. Van Wyk (1979:117-118) som dit soos volg op:

- Die Geneefse psalmmelodieë van 1562 word by die hersiening as basis geneem.

- Die oorspronklike ritme van die melodieë word sover moontlik behou.

- By die vervanging van bestaande melodieë sal gestreef word om melodieë te vind wat stilisties ooreenstem met die Geneefse melodieë. Daarom word eerstens melodieë gesoek in Calvinistiese bundels van die sestiende eeu. As alternatief kan ook nuwe komposisies oorweeg word.

- Die inhoud van teks en melodie moet ten nouste by mekaar aansluit.

- Daar moet deeglik rekening gehou word met melodieë van die Afrikaanse psalmboek wat reeds inslag gevind het. Daarom sal in 'n aantal gevalle naas die Geneefse melodie nog alternatiewe melodieë geduld moet word.

Alhoewel hiermee ' $n$ aantal duidelike en aanvaarbare beginsels gestel is, het die ondersoek van Vos en Müller (1990) en die ondersoek van 2008 sekere leemtes uitgewys waarom die hersiening nie tot grootskaalse aanvaarding van al die melodieë gelei het nie. In die vraelyste wat in 2008 uitgestuur is, het respondente die geleentheid gekry om sekere opmerkings te maak. Tipiese opmerkings is die volgende (Van Rooy 2009:434-436):

- Baie van die Geneefse melodieë sing ons nie. Ons sing eerder psalms op bekende melodieë van gesange.

- Baie van die oënskynlik onsingbare melodieë kán vervang word met ander bekende (en gebruikte) wysies.

- Die psalms in die Psalmboek 2000 is pragtig berym en Skrifgetrou. Ons groot probleem lê egter by die melodieë.

- Ek speel eerder 'n alternatiewe wysie wat singbaar is, as een waar die gemeente brom en nie lekker kan saamsing nie; dit gaan immers daaroor om God te eer en te loof.

\section{Die aanleer van nuwe psalms}

Vos en Müller (1990) het nie in die besonder aandag gegee aan die kwessie van die aanleer van nuwe berymings of melodieë nie, maar het wel bevind, soos aangedui in Afdeling 2, dat die lidmate se houding teenoor die psalms positief is en dat 'n hoë persentasie sou deelneem aan 'n projek om psalmsang te bevorder (vgl Vos \& Müller 1990:96). Die ondersoek is gedoen met die oog op die nuwe omdigting van die psalms en kon dus uiteraard nie veel uitwei oor die aanleer van nuwe liedere of nuwe melodieë nie. In die ondersoek van 
Van Rooy is aandag gegee aan die manier waarop kerke wel, of nie, die nuwe liedere ingeoefen het (2009:449). By die aanleer van nuwe liedere, moet die waarskuwing van Troskie (2001:29) in gedagte gehou word. Nuwe liedere moet aangeleer en ingeoefen word om stagnasie te voorkom. As dit nie ingeoefen word nie, sal die nuwe skatte in 'n nuwe boek onontdek bly.

Nuwe liedere het deur die eeue heen telkens na vore gekom, met verskillende doelstellings en met wisselende sukses. So het die Ambrosiaanse himne ontstaan in die stryd teen die Ariaanse kettery, om die bedreigde Milaanse kerkvolk op te beur (Van der Leeuw \& Bernet Kempers 1939:44). Die strofiese kerklied het van die reformasie af 'n besondere plek in die reformatoriese tradisie ingeneem, maar die oorsprong daarvan gaan terug na Ambrosius (Kloppenburg 1998:266). Calvyn het meerstemmige bewerkings van psalms aanvanklik vir veral huislike gebruik toegelaat (Kloppenburg 1977:45), maar Hasper (1955:403) stel dit sterker, naamlik dat Calvyn meerstemmige musiek buite die erediens bevorder het. Dit wys dat hy die gebruik van die berymde psalms nie net tot die erediens wou beperk nie. Kinders moes die nuwe berymde psalms vooraf by kategese en skole instudeer, sodat hulle tydens eredienste die gemeente met hulle sang kon leer en ondersteun (Brienen 1987:210). Selfs tuis en in die veld moes die liedere ' $n$ middel wees om God te prys en die harte tot Hom te hef om troos te vind in die oorpeinsing van sy deugde, goedheid, wysheid en regverdigheid (Van Andel 1982:80). Calvyn bepleit gemeentesang alvorens hy dit ervaar het (Luth \& Smelik 2001:219). In sy voorwoord (1542) skryf hy: 'Behou jou van misbruik van die gawe, omdat dit harte, sowel ten goede as ten kwade kan beweeg. Die mag van die Woord word deur die melodie versterk, daarom sing ons heilige liedere' (Van der Leeuw \& Bernet Kempers 1939:165-166). Luther het kore gebruik wat die kerklied meerstemmig gesing het, omdat dit aangesluit het by die Duitse kultuur van die sestiende eeu. Die bedoeling was om op dié wyse die jeug in die Christelike leer (in hulle eie landstaal) op te voed (Van der Leeuw \& Bernet Kempers 1939:129). Calvyn verkies gemeentesang en vereis dat die hele gemeente psalms moet kan sing op singbare melodieë (Vrijlandt 1987:88). Vir liturgiese gebruik is 'n rooster opgestel waarvolgens psalms elke Sondagoggend en Sondagmiddag en Woensdae gedurende die erediens gesing is. In 1549 het dit 17 weke geduur om deur al die psalms te gaan, maar nadat die volledige reeks voltooi is, het dit 25 weke geneem. Daar is ongeveer 30 strofes per week gesing. Die rooster het nie Nagmaalsdienste ingesluit nie. Sang was dus 'n dissipline (Brink 2005:21-22; Smelik 1999). Sodoende is die psalms ingeoefen, sodat die gemeente die woorde en die melodie goed geken het, om so die kommunikasie deur die liedere te verhoog.

Carney (1999:20) beveel aan dat verandering in die liturgie of musikale elemente in die erediens teen 'n afgemete pas moet geskied, met inagneming van die gemeente se tradisies en na deeglike kommunikasie. Vernuwing kan desnoods vir 'n proeftydperk ingevoer word. Dit is minder bedreigend as om permanente veranderings sondermeer aan te bring. Gemeentesang behoort op 'n pastorale wyse verander te word. Uitbreiding aan die repertorium is noodsaaklik maar die sleutel tot aktiewe deelname van die lidmate is om die repertorium op 'n sistematies, geduldige wyse op te bou wat gepas is vir beide die gemeente en die liturgie. Indien dit doeltreffend plaasvind, sal die gemeente 'n gevoel van eienaarskap verkry oor die liedere en wat eenmaal nuut was, sal spoedig bekend wees.

Die werk van Golden (1979) is 'n sprekende voorbeeld hiervan. 'n Nuwe Psalm- en Gesangboek is in 1979 in SuidAfrika in gebruik geneem. In die GKSA was daar toe ook 'n nuwe psalmboek, maar die hersiening het alleen met die melodieë verband gehou. Golden (1979:98) wys daarop dat die belangrike doel van so 'n nuwe boek is dat daaruit gesing moet word. Hy gee dan 'n lys van wat gedoen kan word om die gebruik van so 'n nuwe boek te stimuleer (Golden 1979:99-102). Hierin kry kinders 'n besondere plek. Hulle moet nuwe liedere tuis geleer word en die liedere moet 'n plek kry by kategese en jeugbyeenkomste. Sangoefening in die gemeente is 'n volgende uiters belangrike saak. Hy stel voor dat ongeveer 15 minute voor'n erediens daarmee begin kan word. Die liedere moet met oorleg gekies word, met algaande meer aandag aan onbekende melodieë. Sangaande is 'n verdere moontlikheid. Hy lewer ook'n pleidooi vir mense wat ' $n$ aanleg vir sang het om 'n kerngroep in die gemeente te vorm wat die gemeentesang kan ondersteun en bystaan met die aanleer van nuwe liedere tydens sangoefeninge.

Steinmann (1996:19) spreek hom ook baie sterk uit ten gunste van sangoefening voor die erediens, maar dan ook as 'n manier om die gemeente meer in te lig oor die sang. ' $n$ Ingeligte gemeente is 'n geesdriftige gemeente. Die beste geleentheid hiervoor is om voor die aanvang van die erediens ' $n$ sangoefening in te pas. Die ongemotiveerde sing van enige psalm of Skrifberyming bereik niks nie; tewens dit verveel die gemiddelde lidmaat. Die doel van die sangoefening is om elke lied wat gesing gaan word, behoorlik te leer sing, behoorlik te verstaan, presies te weet vir watter doel dit in die erediens gebruik gaan word en met watter gesindheid dit gesing gaan word. Op hierdie wyse kan die gemeente ook spontaan sonder aankondigings antwoord. Die spontane reaksie van die gemeente op die votum en groetseën, Wet, belydenis, Skriflesing en ook as deel van die gebed het veel meer trefkrag en getuig van 'n veel meer betekenisvolle meelewing met die verloop as reaksies wat altyd aangekondig en voorgelees moet word. Dit beteken dat die gemeente vooraf sinvol en geesdriftig voorgegaan moet word in die regte verstaan van en deelname aan die erediens. Op hierdie wyse sal die gemeente se verstaan en liefde vir die kerklied geprikkel word. Daar moet in gedagte gehou word dat byna niemand meer tuis psalms sing nie en die gemiddelde lidmaat hoor byna nêrens enige kerkmusiek as in die kerk nie.

Broekhuijzen (2000:314) doen aan die hand dat wanneer 'n nuwe liedboek in gebruik geneem word, die voorganger 
en die orrelis die verantwoordelikheid dra om toe te sien dat die nuwe liedere tot die repertorium van die gemeente toegevoeg word. Hy stel voor dat daar dan telkens nuwe liedere ingesluit word in voorafoefeninge sodat dit deel kan word van die liturgie. Dit sal daartoe bydra dat die gemeente se repertorium uitgebrei word.

Hopson (2004:11-12) doen 'n aantal baie praktiese voorstelle aan die hand oor die verbetering van gemeentelike sang. Hulle word kortliks genoem:

- Gemeentesang vorm 'n hegte eenheid onder die lidmate. Dit is nie die individu wat sing nie, maar die kerk of gemeente, en die lidmaat mag deel hê aan die sing van die lied.

- Met behoorlike voorbereiding, geduld en volharding kan 'n passiewe gemeente in 'n singende gemeente ontwikkel word.

- Elke geleentheid moet gebruik word om die gemeente op te lei na 'n beter begrip van die liedere wat gesing word.

- Die lied wat die beste gesing word, is die een wat die gemeente met passie kan sing maar wat die lidmaat anders laat aan die einde van die lied.

- Die diversiteit in die gemeente moet aanvaar word en daar moet voorsiening gemaak word daarvoor.

Uit die literatuur blyk dit dus dat inoefening by die ingebruikneming van 'n nuwe liedboek en 'n nuwe beryming baie belangrik is om die liedere te laat inslag vind. Die ondersoek van Van Rooy (2008) het onder andere gehandel oor die vraag van hoe die Psalmboek 2003 in die GKSA gebruik word, ook wat die 2001-omdigting se aanvaarding betref. Uit die ondersoek het daar belangrike inligting na vore gekom oor die ingang wat die 2001-omdigting by die GKSA gehad het. Daar is gemeentes wat die nuwe omdigting sing en daar is ander wat dit nie sing nie. Die predikante is versoek om al die liedere wat hulle oor die periode van 'n jaar laat sing het, aan te dui. Die totaal van al die liedere wat deur al die predikante wat gerespondeer het, oor ' $n$ jaar laat sing is (Tabel 4), is saamgevat (vgl. Van Rooy 2009:356).

Uit al die kerke saam is dus gegewens ontvang oor 15168 keer wat liedere in 'n jaar gesing is. Uit bogenoemde blyk dat die kerke wat die Psalmboek 2000 gebruik, relatief min Skrifberymings sing, ongeveer een Skrifberyming vir elke agt psalms. Die kerke wat die Psalmboek 2003 gebruik, sing meer van die psalms van die 1936-beryming as van die psalms van die 2001-omdigting en die Skrifberymings saam. Hulle sing ongeveer een Skrifberyming vir elke twee psalms van die 1936-beryming en ongeveer vier psalms van die 2001-omdigting vir elke tien psalms van die 1936-beryming. Die kerke wat wel die nuwe omdigting gebruik, het meer Skrifberymings gesing as psalms in die nuwe omdigting, terwyl daar ongeveer die helfte soveel Skrifberymings is as psalms.

Gevolglik is daar ook hieroor vir die predikante en orreliste vrae gevra oor die inoefening van die nuwe omdigting. Die vraag was soos volg (vgl. Van Rooy 2009:449): 'Het julle 'n spesifieke program of plan vir die inoefening van nuwe liedere in die Psalmboek 2003 gebruik?'
TABEL 4: Die totaal van die Psalms 1936 en 2001 in die Psalmboek 2000 en 2003.

\begin{tabular}{lllll}
\hline Psalmboek & $\begin{array}{l}\text { 1936- } \\
\text { beryming }\end{array}$ & $\begin{array}{l}\text { Skrif- } \\
\text { berymings }\end{array}$ & $\begin{array}{l}\text { 2001- } \\
\text { omdigting }\end{array}$ & Totaal \\
\hline Psalmboek 2000 & 2792 & 403 & - & 3195 \\
Psalmboek 2003 & 6447 & 3107 & 2419 & 11973 \\
\hline Totaal & $\mathbf{9 2 3 9}$ & $\mathbf{3 5 3 0}$ & $\mathbf{2 4 1 9}$ & $\mathbf{1 5 1 6 8}$ \\
\hline
\end{tabular}

Tabel 5: Inoefeningsprogram vir die Psalmboek 2003.

\begin{tabular}{lcc}
\hline Antwoord & \multicolumn{3}{c}{} \\
\cline { 2 - 3 } & Predikante & Orreliste \\
\hline Ja & 40 & 32 \\
Nee & 60 & 68 \\
\hline
\end{tabular}

Dit is duidelik dat die aanleer van nuwe liedere, wat woorde en melodie betref, baie belangrik is vir die aanvaarding van 'n nuwe liedboek. Die feit dat die minderheid kerke in die GKSA wel die nuwe liedere ingeoefen het, kan een van die redes wees waarom die 2001-omdigting nog relatief min gesing word by die kerke wat dit wel sing.

\section{Slotsom}

Hierdie artikel bied 'n vergelyking van belangrike gegewens uit twee ondersoeke na die sing van psalms in Afrikaanssprekende gereformeerde gemeentes in SuidAfrika. Die ondersoek van Vos en Müller (1990) berus op gegewens van 'n RGN-ondersoek wat gedoen is met die oog op 'n nuwe psalmberyming. Die ondersoek van 2008 (Van Rooy 2009) bied gegewens oor die aanvaarding van die nuwe beryming in een van die Afrikaanssprekende gereformeerde kerke waar die nuwe beryming gebruik word. Die vergelyking toon aan dat die aantal gewilde psalms en die gewilde psalms self grotendeels konstant gebly het. Die redes waarom sekere liedere nie maklik ingang vind nie, hang saam met verskillende faktore, waaronder die aanvaarding van die melodie en liturgiese bruikbaarheid belangrike rolle speel. Die feit dat die nuwe liedere nog nie behoorlik benut word in die GKSA nie, hou ten dele verband met die gebrek aan programme van inoefening en aanleer van die nuwe liedere, veral wat die melodieë betref.

\section{Literatuurverwysings}

Brienen, T., 1987, De liturgie by Johannes Calvyn [Die liturgie deur Johannes Calvyn], De Groot Goudriaan, Kampen.

Brink, E.R., 2005, 'A reformed approach to psalmody: The legacy of the Genevan Psalter' ['n Gereformeerde benadering tot psalmgesang: die nalatenskap van die Geneefse Psalmboek], The hymn 56(1), 16-25.

Broekhuijzen, G., 2000, 'Liedbundel voor de liturgie' [Liedbundel vir die liturgie], Tijdschrift voor Liturgie 84(3), 303-314.

Carney, M., 1999, 'Liturgical music in the Postmodern Age' [Liturgiese musiek in die Postmoderne Era], The hymn 50(1), 15-23.

Cilliers, P.J., 1979, 'Die begeleiding en die melodie van die kerklied', in J.A. Loader (red.), 'n Nuwe lied vir die Here. Opstelle by die verskyning van die nuwe Afrikaanse Psalm- en Gesangboek, pp. 76-88, HAUM, Pretoria/Kaapstad.

Dingemans, G.D.J., 1996, Manieren van doen. Inleiding tot de studie van de Praktische Theologie [Maniere van doen. Inleiding tot die studie van Praktiese Teologie], Kok, Kampen.

Golden, S.G.A., 1979, 'Kerksang in Nederland en Suid-Afrika vandag', in J.A. Loader (red.), 'n Nuwe lied vir die Here. Opstelle by die verskyning van die nuwe Afrikaanse Psalm- en Gesangboek, pp. 89-111, HAUM, Pretoria/Kaapstad.

Gottlieb, A., 2006, 'Ethnography: Theory and methods' [Etnografie: Teorie en Metodes], in E. Perecman \& S.R. Curran (eds.), A handbook for Social Science Research, pp. 47-68, SAGE Publications, Thousand Oaks/ London/New Delhi. 
Hasper, H., 1955, Calvijns beginsel voor de zang in de eredienst verklaart uit de Heilige Schrift en uit de geschiedenis der kerk. Een kerkhistorisch en hymnologisch onderzoek. Deel l [Calvyn se beginsels vir die sang in die erediens soos verklaar onderzoek. Deel I [Calvyn se beginsels vir die sang in die erediens soos verklaar
uit die Heilige Skrif en uit die kerkgeskiedenis. 'n Kerkhistoriese en himnologiese uit die Heilige Skrif en uit die kerkgeskiedenis. ' $n$ Kerkhistoriese en himnologiese
ondersoek. Deel I], Stichting geestelijke liederen uit den schat van de kerk der ondersoek. Deel I], Stich
eeuwen, 's-Gravenhage.

Honders, A.C., (red.), 1978, Klinkend geloof. Uit de geschiedenis van de Nederlandse kerkelijk en geestelijk lied [Klinkende geloof. Uit die geskiedenis van die Nederlandse kerk- en geestelike lied], Boekencentrum, 's-Gravenhage.

Hopson, H.H., 2004, 'Ways to improve congregational singing' [Maniere om gemeentesang te verbeter], The hymn 53(1), 11-16.

Kloppenburg, W., 1998, 'Het kerklied' [Die kerklied], in P. Oskamp \& N. Schuman (reds.), De weg van de liturgie. Tradities, achtergronden, praktijk, 2de druk, pp. 266-279, Meinema, Zoetermeer.

Kloppenburg, W., 1991, 'Psalmlied en Volkslied', in J. de Bruijn (red.), Psalmzingen in de Nederlanden. Vanaf de zestiende eeuw tot heden, pp. 233-244, Kok, Kampen.

Kloppenburg, W., 1977, 'De melodieën van het Geneefse psalter' [Die melodieë van die Geneefse psalmboek], in W.G. Overbosch (red.), Een compendium van achtergrondinformatie bij de 491 Gezangen uit het Liedboek voor de Kerken, pp. achtergrondinformatie bij de 491 Gezangen uit het Lied

Luth, J. \& Smelik, J., 2001, 'Die Calvinistiese traditie' [Die Calvinistiese tradisie], in J. Luth, J. Pasveer \& J. Smelik (reds.), Het Kerklied. Een geschiedenis, pp. 217-286, Mozaiek, Zoetermeer.

Marais, H.C. \& Bondesio, M.J., 1996, 'Navorsingsbestuur', in J.G. Garbers (red.), Doeltreffende geesteswetenskaplike navorsing. Navorsingsbestuur vir navorsers, studieleiers en M- en D-kandidate, pp. 117-146, J.L. van Schaik, Pretoria.

Olivier, G., 2001, '"Singbare" melodieë', Vir die musiekleier 28, 42-45.

Pasveer, J., 2001, 'Postludium', in J. Luth, J. Pasveer \& J. Smelik (reds.), Het kerklied. Een geschiedenis, pp. 328-334, Mozaiek, Zoetermeer.

Psalmboek, 2003, Die berymde en omgedigte Psalms en ander Skrifberyminge in die gebruik by die Gereformeerde Kerke in Suid-Afrika, NG Kerk-Uitgewers, Wellington.
Psalmboek, 2000, Die berymde Psalms in gebruik by die Nederduitse Gereformeerde Kerk, die Gereformeerde Kerke in Suid-Afrika, die Nederduitsch Hervormde Kerk van Afrika en Skrifberymings in die gebruik by die Gereformeerde Kerke in Suidvan Afrika en Skrifberymings
Afrika, CJBF, Potchefstroom.

Smelik, J., 1999, 'Omgaan met kerkliederen: respect voor de diversiteit' [Omgang met kerkliedere: respek vir diversiteit], Eredienst 26(4), 128-134.

Steinmann, R., 1996, 'Gemeentesang en begeleiding', Vir die musiekleier 23, 15-19.

Troskie, A., 2001, 'Liedboek van die Kerk - praktiese gebruik vir orrelis en leraar', Vir die musiekleier 28, 25-31.

Van Andel, C.P., 1982, Tussen de regels. De samehang van kerkgeschiedenis en kerklied [Tussen die reëls. Die onderlinge afhanklikheid van kerkgeskiedenis en kerkliedere], 2de druk, Boekencentrum, 's-Gravenhage.

Van der Leeuw, G. \& Bernet Kempers, K. Ph., 1939, Beknopte geschiedenis van het kerklied [Beknopte geskiedenis van die kerklied], Wolters, Groningen.

Van der Merwe, H., 1996, 'Die navorsingsproses: probleemstelling en navorsing. Navorsingsbestuur vir navorsers, studieleiers en $M$ - en $D$-kandidate, pp. 285-300, J.L. van Schaik, Pretoria.

Van Rooy, J.H., 2009, Die Psalmboek 2003 as kommunikasiemiddel in die liturgie van die erediens in die Gereformeerde Kerke in Suid-Afrika: 'n himnologiese studie, PhD-proefskrif, Skool vir kerkwetenskappe, Vakgroep Praktiese Teologie, Noordwes-Universiteit, Potchefstroom.

Van Wyk, D.J.C., 1979, 'Hervormde medewerking aan 'n Afrikaanse Psalm- en Gesangboek 1928-1978', in J.A. Loader (red.), 'n Nuwe lied vir die Here. Opstelle by die verskyning van die nuwe Afrikaanse Psalm- en Gesangboek, pp. 112-140, HAUM, Pretoria/Kaapstad.

Vos, C.J.A. \& Müller, J.C., 1990, 'Die sing van psalms in die erediens:'n Kommunikatiewe handelingsteoretiese perspektief', Praktiese Teologie in Suid-Afrika 6(1), 86-98.

Vrijlandt, M.A., 1987, Liturgiek, Meinema, Delft.

Yates, S.J., 2004, Doing social science research [Sosiaal-wetenskaplike navorsing], SAGE Publications, London/Thousand Oaks/New Delhi.

Zerfass, R., 1988, 'Gottesdiens als Handlungsfeld der Kirche' [Die erediens as handelingsveld van die kerk], Liturgisches Jahrbuch 38(1/2), pp. 30-59. 